Л. Б. Бондаренко ${ }^{1}$, Т. А. Карацуба ${ }^{1}$, О. О. Хавич ${ }^{1}$,

Г. М. Шаяхметова ${ }^{1}$, Н. І. Шарикіна ${ }^{1}$, В. М. Коваленко ${ }^{1}$,

Р. О. Стратійчук ${ }^{2}$, А. А. Коновалов ${ }^{2}$, М. М. Калачінська ${ }^{3}$

\title{
Вплив Іфітинібу на складові хроматину та стан антиоксидантної системи в карциномі Герена та незмінених тканинах матки
}

\author{
${ }^{1}$ Державна установа «Інститут фармакології та токсикології \\ Національної академії медичних наук України», м. Київ \\ ${ }^{2}$ Навчально-науковий центр «Інститут біології і медицини» \\ Київського національного університету ім. Т. Г. Шевченка, м. Київ \\ ${ }^{3}$ Відкритий міжнародний університет розвитку людини «Україна», м. Київ
}

Ключові слова: Іфітиніб, карцинома Герена, ДНК, РНК, фрагментація, антиоксидантна система

Одне з провідних місць серед існуючих методів лікування онкологічних хворих займає хіміотерапія [1]. IIÏ застосовують як самостійний метод або як компонент комплексного лікування. Інтенсивний пошук нових високоефективних протипухлинних препаратів $\mathrm{E}$ однією 3 найнагальніших проблем сучасної онкофармакології.

Однак призначення протипухлинних засобів пов'язане 3 низкою суттєвих проблем [2]. Одна з них полягає в неспецифічності дії протипухлинних препаратів і високій токсичності щодо органів і тканин, неуражених пухлиною [3, 4], зокрема, наявністю в них серйозної кардіо-, нефро- та нейротоксичності [5]. Ситуація ускладнюється тією обставиною, що більшість досліджень з онкофармакології традиційно фокусувалось на виявленні специфічної дії протипухлинних засобів стосовно тканин саме пухлин, тоді як на стан прилеглих тканин, які не були захоплені інвазією пухлини, звертали мало уваги. Вивчення біохімічних змін у цих тканинах проводилось не системно, наявні розрізнені дані, в основному одержані в ході токсикологічних випробувань.

У той самий час навіть наявні результати [3-5] свідчать, що неспецифічна дія протипухлинної хіміотерапії на

(C) Колектив авторів, 2019 прилеглі до пухлини тканини сама по собі здатна погіршити стан організму додатково до наслідків розвитку неопластичного процесу в ньому i, навіть, справити вирішальну роль у виживанні організму.

У зв'язку з усім вищезгаданим актуальним $є$ проведення паралельних досліджень впливу нових протипухлинних засобів на етапі доклінічних випробувань як на пухлини, так і на тканини того самого організму, які не уражені неопластичними змінами, для подальшої оптимізації хіміотерапії.

Мета дослідження - вивчити вплив Іфітинібу на ДНК, РНК, білки хроматину, процеси фрагментації ДНК, вміст небілкових i пов'язаних 3 білками SH-груп у карциномі Герена та незмінених тканинах матки.

Матеріали та методи. Дослідження впливу Іфітинібу проводили на білих щурах-самицях лінії Вістар масою 150-250 г, вирощених у віварії ДУ «ннститут фармакології та токсикології НАМНУ». Тварин утримували на стандартному харчовому раціоні за умов вільного доступу до води. План досліджень був розглянутий i схвалений Комітетом 3 біоетики ДУ «Інститут фармакології та токсикології НАМНУ» . Усі процедури, що пов'язані з гуманним поводженням із тваринами та їхнім використанням у експериментах, були дотримані. Тварин розподіляли на групи за методом рандомізації з попереднім карантином протягом 7 діб. 
Іфітиніб було синтезовано у відділі медичної хімії ДУ «Інститут фармакології та токсикології НАМНУ».

Вплив Іфітинібу на складові хроматину та стан антиоксидантної системи вивчали за умов експериментальної моделі карциноми Герена, яку одержували шляхом трансплантації тваринам за стандартними методами [6]. Тварини були розподілені за методом рандомізації на 3 групи по 6 тварин у кожній: 1 - інтактні щури; 2 - негативний контроль (карцинома Герена); 3 - карцинома Герена $+29,93$ мг/кг Іфітинібу. Структурну формулу Іфітинібу надано на рисунку 1.

Тваринам III групи перорально вводили Іфітиніб, а щурам I і II груп - відповідний об'єм 0,9 \% водного розчину хлориду натрію. Введення проводили кожні 48 год, розпочинаючи з наступної доби після трансплантації карциноми Герена, протягом двох тижнів. На 15 добу експерименту (після 24 год голодування) тварин зважували, потім під легким ефірним наркозом у них брали кров зі стегнової вени, знеживлювали методом цервікальної дислокації й вилучали пухлини та відповідні тканини без неопластичних змін для подальших досліджень.

Заморожені в рідкому азоті тканини гомогенізували та виділяли геномну ДНК, РНК і білки [7].

Для виділення нуклеїнових кислот гомогенізацію зразка (50 мкг) проводили в 1 мл TRI-реагенту («Sigma», США), після чого додавали 200 мкл хлороформу, струшували й залишали стояти за кімнатної температури протягом 15 хв. Далі центрифугува-

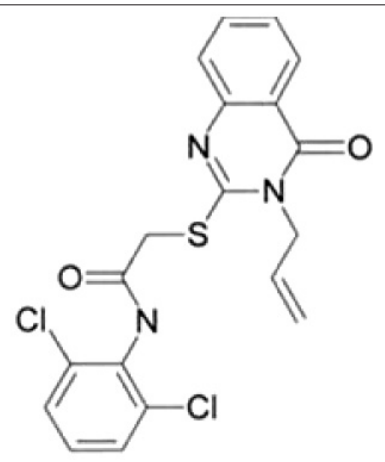

Рис. 1. Структурна форлула Іфітинібу ли $\left(12000 \mathrm{~g}, 2{ }^{\circ} \mathrm{C}, 15 \mathrm{xв}\right)$, після чого розчин розділився на три фази: червону (білки), білу (містить ДНК) і безбарвну фазу (містить РНК). Фракції акуратно розшаровували окремо по пробіркам для очищення та визначення вмісту.

Для виділення РНК у мікропробірку з відібраною безбарвною фазою додавали 0,5 мл ізопропанолу, відстоювали 5-10 хв за кімнатної температури i центрифугували $\left(12000 \mathrm{~g}, 2{ }^{\circ} \mathrm{C}, 10\right.$ хв), зливали супернатант. До осаду додавали 75 \% етанол до об'єму 2 мл, центрифугували за $12000 \mathrm{~g}, 2{ }^{\circ} \mathrm{C}, 5$ хв, зливали супернатант. Процедуру повторювали двічі. Одержаний зразок РНК висушували та розводили в 100 мкл DEPCводи.

Для виділення ДНК в епендорф з відібраною фракцією додавали 0,3 мл $100 \%$ етанолу, відстоювали 2-3 хв за кімнатної температури, центрифугували $\left(2000 \mathrm{~g}, 2{ }^{\circ} \mathrm{C}, 5 \mathrm{xв}\right)$, зливали супернатант. До осаду додавали розчин 0,1 моль/л цитрату натрію в $10 \%$ етанолі (2 мл), відстоювали 30 хв, центрифугували за тих самих умов, зливали супернатант. Осад промивали 2 рази в $70 \%$ етанолі, як зазначено вище, та висушували. Одержаний зразок ДНК висушували та розводили в 100 мкл DEРС-води.

Спектрофотометричне визначення концентрації ДНК і РНК проводили за загальноприйнятим методом [8]. Вимірювали поглинання світла за довжини хвилі 260 нм. Розрахували концентрацію ДНК, використовуючи коефіцієнт перерахунку 6,5 за формулою:

$$
\mathrm{C}_{\text {днк }}\left[\text { мкг /мл] }=\mathrm{A}_{260} 6,5\right. \text {. }
$$

Аналогічно проводили визначення вмісту РНК і розрахували її концентрацію, використовуючи коефіцієнт перерахунку 5,2 за формулою:

$$
\mathrm{C}_{\text {Рнк }}[\text { мкг } / \mathrm{мл}]=\mathrm{A}_{260} 5,2 \text {. }
$$

Вміст гістонів визначали за модифікованим методом М. Г. Трудолюбової [9].

Для визначення ступеня фрагментації ДНК розчиняли у ТВЕ буфері (10 ммоль/л Tris-HCl і 1 ммоль/л EDTA, pH 8) і розділяли в $2 \%$ агарозному гелі 80B; 
83 мА, 6 W, 2 год. Після завершення електрофорезу гелі забарвлювали розчином бромистого етидію (5 мкг/мл) і фотографували в УФ-світлі за допомогою системи GelDoc («BioRad», СШA) [10].

У гомогенатах тканин також визначали вміст небілкових і пов'язаних 3 білками SH-груп [11].

Отримані дані представляли як середнє значення \pm похибка середнього $(\mathrm{M} \pm \mathrm{m})$. Статистичний аналіз результатів експерименту проводили 3 використанням однофакторного дисперсійного аналізу (ANOVA). Різницю між досліджуваними показниками вважали статистично вірогідною в разі $\mathrm{p} \leq 0,05$.

Результати та їх обговорення. Ушкодження будь-яких внутрішньоклітинних макромолекул (ДНК, РНК, протеїнів, ліпідів) внаслідок розвитку онкологічного процесу може мати принципове значення для життєдіяльності клітини, а значні відхилення їхнього вмісту від нормального рівня - призводити до пошкодження клітини та її загибелі.

ДНК - важлива молекулярна мішень для низки сполук, яка піддається летальному розщепленню індукованими ними ендонуклеазами [12]. Рівень і характер фрагментації ДНК є марке- ром протікання процесів апоптозу в організмі [13].

Результати вивчення впливу пухлини Герена та ї̈ лікування препаратом Іфітиніб на процеси фрагментації ДНК наведені на рисунку 2.

Як видно з фотографій електрофореграм, як за умов розвитку пухлини, так і за умов введення препарату Іфітиніб відбувається суттєва інтенсифікація процесів фрагментації ДНК у клітинах. Це цілком відповідае даним інших авторів, які відзначали, що рівень фрагментації ДНК звичайно коливається в межах 5-8 \% у здоровому організмі за нормальних умов, а за умов розвитку навіть передонкологічного процесу відбувається його значне посилення [14].

За умов розвитку пухлини Герена у наших експериментах кількість фрагментів ДНК сягала 22. Із них фрагментів із довжинами молекул від 1000 пар основ до 500 пар основ було 10; фрагментів із довжинами молекул від 500 пар основ до 200 пар основ - 5; фрагментів із довжинами молекул від 200 пар основ до 20 пар - 7. Причому за вмістом переважали фрагменти ДНК із середніми розмірами (від 1000 до 500 пар основ).
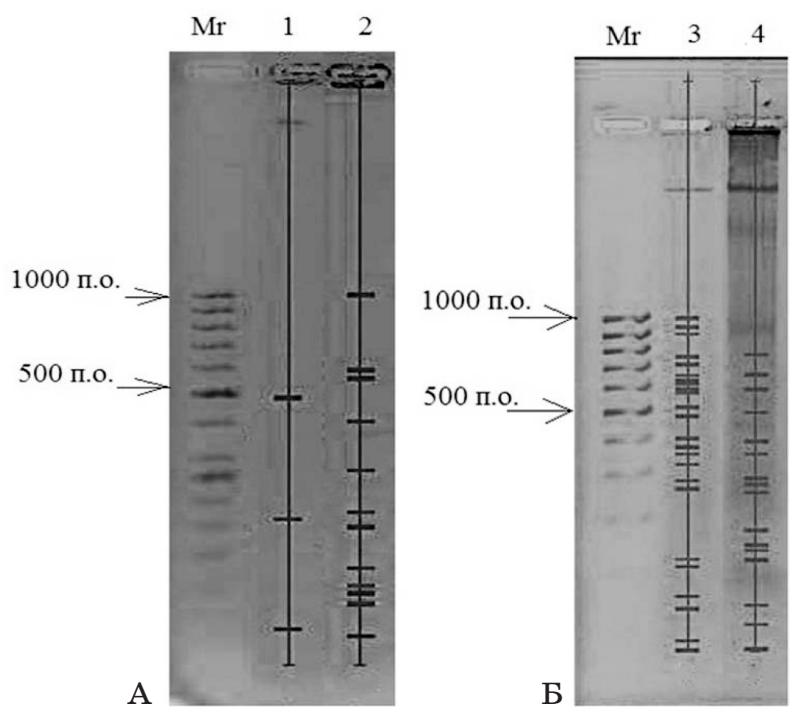

Рис. 2. Рівень фрагментацї ДНК у тканині карциноли Герена (Б) та неуражених пухлиною тканинах матки (А) за улов введення шурал Іфітинібу

Прилітка. 1 - інтактний контроль, 2 - тканина, яка неуражена пухлиною + Іфітиніб, 3 -кариинола Герена, 4 - кариинома Герена + Іфітиніб. 
Ці дані цілком узгоджуються 3 результатами інших авторів, зокрема, в експериментах на білих безпородних щурах-самцях масою 120-160 г [15] було показано, що пошкодження ДНК чітко корелювало з ростом карциноми Герена в експериментальних тварин.

Лікування препаратом Іфітиніб призводило до деякого зменшення числа фрагментів ДНК у клітинах пухлини Герена - до 16 і зміни характеру самої фрагментації. Так, із цих 16 фрагментів 3 довжинами молекул від 1000 до 500 пар основ було 3 ; фрагментів з довжинами молекул від 500 до 200 пар основ було в середньому 5; фрагментів 3 довжинами молекул від 200 пар основ до 20 пар - 8. Причому за вмістом переважали фрагменти ДНК із найменшими розмірами (від 200 до 20 пар основ).

У неуражених пухлинами тканинах введення Іфітинібу призводило до утворення 12 фрагментів ДНК. Із цих 12 фрагментів 3 довжинами молекул від 1000 до 500 пар основ було 3; фрагментів 3 довжинами молекул від 500 до 200 пар основ було в середньому - 2; фрагментів з довжинами молекул від 200 пар основ до 20 пар - 7. Причому за вмістом переважали фрагменти ДНК з найменшими розмірами (від 200 до 20 пар основ).

Результати визначення процента фрагментації ДНК в експериментальних тварин наведені в таблиці 1. Із наведених даних видно, що як розвиток пухлини, так i саме введення препарату призводили до зростання процента фрагментації ДНК. Спостерігається певна тенденція до зниження відсотка фрагментації ДНК за умов лікування карциноми Герена препаратом Іфітиніб.

Відзначений нами вплив Іфітинібу на ДНК на тлі онкологічного процесу може бути пов'язаний з його здатністю спричиняти цитостатичний ефект на клітини пухлин, що супроводжується пригніченням їхньої мітотичної активності. Подібну активність має Етопозид, що гальмує мітотичну активність клітин карциноми Герена, що проявляється через добу як у разі окремого застосування, так і в комбінації з опроміненням і супроводжується зростанням числа клітин пухлини невеликого розміру [16]. У цьому разі апоптотична активність клітин гальмується.

Не можна також виключати можливість реалізації ефекту за рахунок взаємодії 3 протеїнами 3 сімейства Bcl-2, що є ключовим регулятором залежного від мітохондрій апоптозу в клітині та включае як антиапоптотичні (Bcl-xL, Bcl-2, Bcl-w, A1, Mcl-1), так і проапоптотичні (Bak, Bax, Bid, Bim, Bad, Bik, Bmf, Noxa, Puma) білки [17]. Такі властивості вже виявлені в низки хімічних сполук, що містять у своїй структурі орто-конденсовані системи (зокрема, карбацефами, гомотієнаміцини) [17].

Крім того, треба мати на увазі й існування шляху опосередкованого впливу цитостатика на процеси фрагментації ДНК. Показано, що критичним компонентом сигналінгу в опромінених клітинах є метаболіт сфінголіпідів - церамід, який відіграє центральну роль у сигнальній трансдукції, у регуляції диференціювання клітин, арешті клітинного циклу та бере участь в апоптозі [18]. Генерація цієї сполуки є важливим етапом в індукції загибелі пухлинних клітин цитотоксичними агентами. Цитотоксичний ефект пов'язаний 3 активацією апоптозу через церамідопосередковані шляхи.

Однак механізми накопичення, обміну сфінголіпідів за дії хіміопрепаратів, у яких превалює цитостатична, а не цитотоксична активність у пухлині,

Таблиця 1

Прочент фрагментацї ДНК в експериментальних тварин

\begin{tabular}{|l|c|c|c|c|}
\hline \multirow{2}{*}{ Показник } & \multicolumn{4}{|c|}{ Експериментальна група } \\
\cline { 2 - 5 } & $\begin{array}{c}\text { тканина } \\
\text { матки } \\
\text { (інтактний } \\
\text { контроль) }\end{array}$ & $\begin{array}{c}\text { неуражена тканина } \\
\text { матки щурів 3 кар- } \\
\text { циномою Герена + } \\
\text { Іфітиніб }\end{array}$ & $\begin{array}{c}\text { карцинома } \\
\text { Герена } \\
\text { (негативний } \\
\text { контроль) }\end{array}$ & $\begin{array}{c}\text { карцинома } \\
\text { Герена + } \\
\text { Іфітиніб }\end{array}$ \\
\hline $\begin{array}{l}\text { Фрагментація } \\
\text { ДНК, \% }\end{array}$ & 11,92 & 45,34 & 61,99 & 53,43 \\
\hline
\end{tabular}


залишаються маловивченими. Різними групами дослідників показано, що превалювання цитостатичної чи цитотоксичної активності в різних препаратів, що застосовуються для хіміотерапії різних пухлин, сильно варіюе як залежно від хімічної природи препарату, так і від типу пухлини та поєднання препаратів у комбінації з радіоопроміненням [19].

Зокрема, Етопозид сам по собі послаблює апоптотичну загибель клітин [16], а в поєднанні з радіоопроміненням стимулює, так само, як і Таксотер [20]. Поєднана дія опромінення та цих хіміопрепаратів є індуктором накопичення в тканині пухлини Герена активатора апоптозу ракових клітин цераміду, тоді як цисплатин активує сфінгомієліновий шлях накопичення цераміду в пухлинних клітинах.

Було досліджено вміст РНК, ДНК, співвідношення РНК/ДНК, вміст РНК відносно загального вмісту нуклеїнових кислот і вміст гістонів у пухлині Герена й за лікування препаратом Іфітиніб.

Із наведених даних (табл. 2) видно, що статистично вірогідних змін ДНК за умов розвитку пухлини Герена та їі лікування Інфітинібом не відзначалось ні у власне пухлинах, ні у тканинах, які не уражені неопластичними змінами. Відбувалось вірогідне зростання вмісту РНК, співвідношення РНК/ДНК, співвідношення РНК до загального вмісту нуклеїнових кислот у пухлині Герена як з лікуванням, так і без, тоді як у тканинах, які не уражені неопластичними змінами, ці показники вірогідно не відрізнялися від інтактного контролю. Одночасно спостерігалося вірогідне зниження вмісту гістонових білків за даних умов експерименту, що може свідчити про зменшення стабільності структури хроматину за пухлинного росту та хіміотерапії похідними хіназоліну.

Одержані результати цілком узгоджуються з даними літератури. Загалом відомо, що в нормальних соматичних клітинах кількість ДНК, основного носія генетичної інформації, є стабільною [20], тоді як кількість РНК, що безпосередньо бере участь у синтезі білка, змінюється залежно від віку, життєвої стадії, наявності захворювань й умов навколишнього середовища [20]. Таким чином, вважають, що клітини, які перебувають у стабільному стані, як правило, мають більш високі співвідношення РНК/ДНК, ніж ті, які мають

Таблиця 2

Вміст нуклеїнових кислот, їхні співвідношення та вміст гістонів у клітинах карииноми Герена і тканин матки без неопластични змін за умов введення шурал тест-зразка Іфітинібу

\begin{tabular}{|c|c|c|c|c|}
\hline \multirow[b]{2}{*}{ Показник } & \multicolumn{4}{|c|}{ Експериментальна група } \\
\hline & $\begin{array}{l}\text { тканина } \\
\text { матки } \\
\text { (інтактний } \\
\text { контроль) }\end{array}$ & $\begin{array}{c}\text { неуражена тканина } \\
\text { матки щурів з кар- } \\
\text { циномою Герена + } \\
\text { Іфітиніб }\end{array}$ & $\begin{array}{l}\text { карцинома } \\
\text { Герена (нега- } \\
\text { тивний } \\
\text { контроль) }\end{array}$ & $\begin{array}{l}\text { карцинома } \\
\text { Герена + } \\
\text { Іфітиніб }\end{array}$ \\
\hline $\begin{array}{l}\text { Вміст РНК, } \\
\text { мкг/мг білка }\end{array}$ & $31,43 \pm 3,57$ & $28,28 \pm 4,36^{\#, \&}$ & $90,92 \pm 16,48^{\star}$ & $82,37 \pm 23,74^{\star}$ \\
\hline $\begin{array}{l}\text { Вміст ДНК, } \\
\text { мкг/мг білка }\end{array}$ & $105,37 \pm 2,29$ & $102,0 \pm 46,0$ & $98,68 \pm 0,68$ & $105,37 \pm 2,28$ \\
\hline $\begin{array}{l}\text { Співвідношення } \\
\text { РНК/ДНК, у. о. }\end{array}$ & $0,30 \pm 0,04$ & $0,29 \pm 0,04^{\#, \&}$ & $0,92 \pm 0,16^{\star}$ & $0,78 \pm 0,23^{\star}$ \\
\hline $\begin{array}{l}\text { Співвідношення } \\
\text { РНК і загального } \\
\text { вмісту нуклеїно- } \\
\text { вих кислот, у. о. }\end{array}$ & $0,23 \pm 0,02$ & $0,20 \pm 0,03^{\#, \&}$ & $0,48 \pm 0,04^{\star}$ & $0,42 \pm 0,08^{*}$ \\
\hline $\begin{array}{l}\text { Гістони, мг/мг } \\
\text { тканини }\end{array}$ & $0,55 \pm 0,02$ & $0,46 \pm 0,02^{*}$ & $0,33 \pm 0,03^{*}$ & $0,48 \pm 0,04^{\#}$ \\
\hline
\end{tabular}

Прилітка. *p < 0,05 порівняно з інтактним контролел, ${ }^{*} p<0,05$ порівняно з показником групи з пухлинами без введення препарату, ${ }^{\star} p<0,05$ порівняно з показникол групи з пухлинали та введеннял препарату. 
відхилення від норми [21]. 3 іншого боку, аналіз вмісту ДНК і РНК у неопластичних клітинах [22] свідчить про зростання вмісту РНК і ДНК. Найбільші значення ДНК і РНК виявляють у метастазуючих карциномах (виключенням є зниження кількості РНК у пухлинах середньої диференціації). Більше того, з переходом процесу метастазування на наступний етап за умов зростання рівнів ДНК і РНК може знижуватись їхне співвідношення. Збільшення кількості нуклеїнових кислот у ракових клітинах може свідчити про підвищення ризику розвитку пухлинних депозитів і закономірно зростае 3 кожним подальшим етапом метастазування [22].

Дані, що наведені в таблиці 2, демонструють незначну тенденцію до зростання вмісту ДНК і тенденцію до зниження вмісту РНК та гістонів у результаті лікування карциноми Герена препаратом Іфітиніб порівняно з нелікованою пухлиною. Останнє, зокрема, може свідчити про включення механізмів гальмування мітотичного циклу [23] у клітинах пухлини під дією Іфітинібу, що $\epsilon$ додатковим підтвердженням нашого припущення щодо переважання цитостатичного ефекту цього препарату за його дії на пухлинні клітини. Одночасно нами виявлено тенденцію до зниження співвідношення РНК/ДНК і $\mathrm{PHK/(РНК} \mathrm{+} \mathrm{ДНК).} \mathrm{Ми} \mathrm{в} \mathrm{даному} \mathrm{випад-}$ ку розглядаємо цей феномен як позитивний, оскільки відношення вмісту РНК до загального вмісту нуклеїнових кислот $[\alpha \mathrm{r}=$ РНК / $($ РНК + ДНК)] забезпечує чутливий аналіз будь-яких відхилень від збалансованого клітинного росту [24]. Таким чином, на нашу думку, подібні результати можуть свідчити про порушення зростання неопластичних клітин внаслідок застосування досліджуваного агента.

Характер змін досліджуваних показників у тканинах без неопластичних процесів свідчить про аналогічну дію даного препарату як на пухлини, так i на неушкоджені клітини.

На рисунку 3 наведено результати дослідження вмісту небілкових i

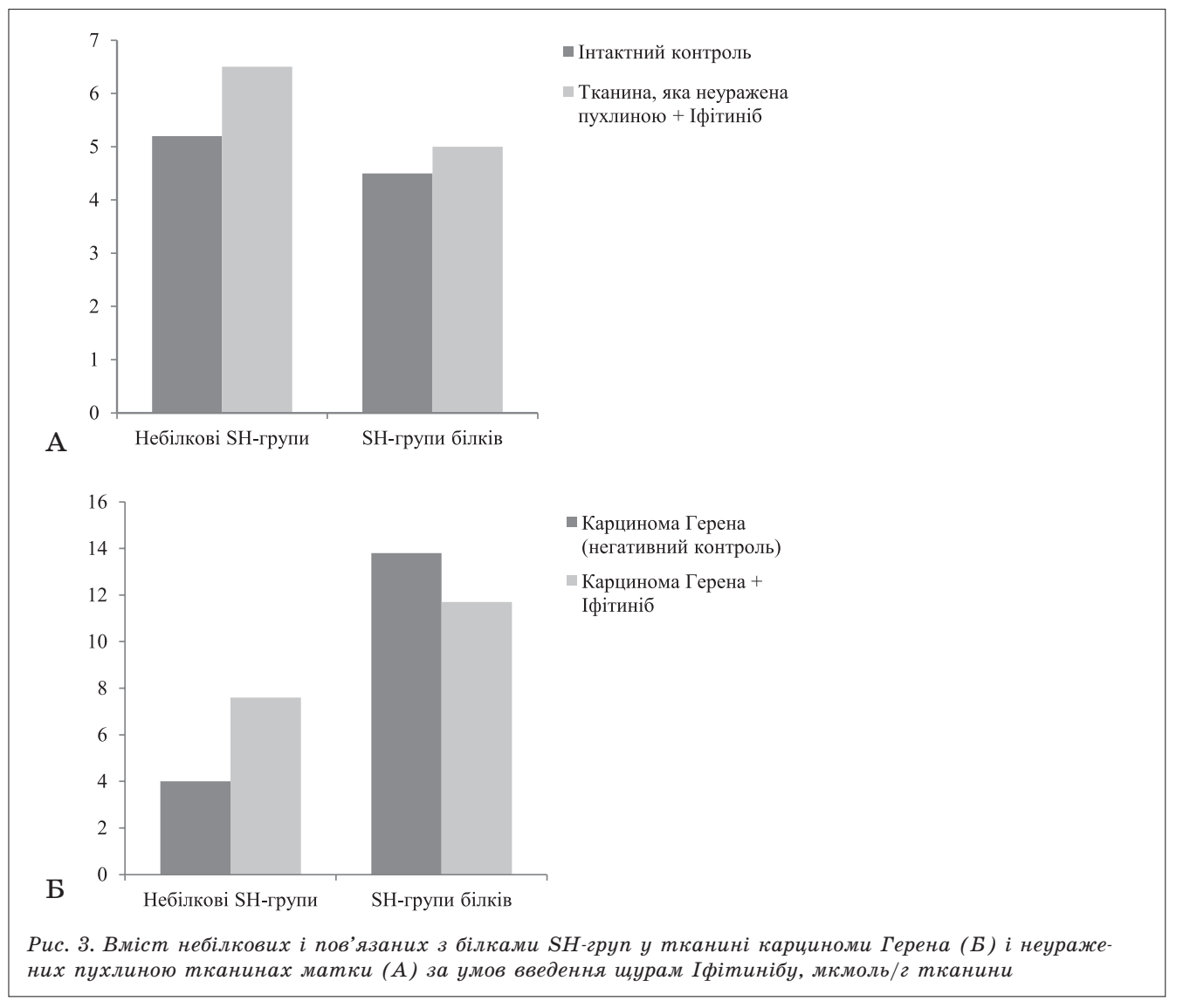


пов'язаних з білками SH-груп у тканині карциноми Герена та неуражених пухлиною тканинах за умов введення щурам Іфітинібу. За умов розвитку карциноми Герена відбувається суттєве зниження вмісту небілко-

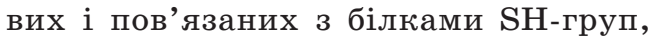
що не може не позначитись на стані систем антиоксидантного захисту клітин організму [25]. Лікування Іфітинібом дозволяе частково нормалізувати ці показники. Цікаво, що на відміну від тканини пухлини в неуражених пухлиною тканинах вірогідний ефект досліджуваного препарату відсутній, що може вказувати на наявність специфічного не лише цитостатичного, але й опосередкованого впливом на системи антиоксидантного захисту ефекту Іфітинібу на карциному Герена.

\section{Висновки}

Вивчення впливу Іфітинібу на ДНК, РНК, білки хроматину, процеси фрагментації ДНК, вміст небілкових і пов'язаних з білками SH-груп у карциномі Герена та незмінених тканинах матки показало, що даний препарат вірогідно змінював більшість досліджуваних показників як порівняно з інтактними тваринами, так і 3 карциномою Герена без лікування. При цьому специфічність впливу Іфітинібу на клітини пухлин була найвираженішою у випадку ДНК-фрагментації та змін вмісту небілкових і пов'язаних з білками SH-груп.

1. Subgroup effects in a randomised trial of different types and doses of exercise during breast cancer chemotherapy. K. S. Courneya, D. C. McKenzie, J. R.Mackey et al. Br J Cancer. 2014. V. 111. P. 1718-1725. https://doi.org/ 10.1038/bjc.2014.466.

2. Nanoscale drug delivery strategies for therapy of ovarian cancer: conventional vs targeted. S. Gupta, Y. Pathak, M. K. Gupta, S. P. Vyas. Artif Cells Nanomed Biotechnol. 2019. V. 47. P. 4066-4088. https://doi.org/ 10.1080/21691401.2019.1677680.

3. Smithson C. R., Schneider S. M. Ibrutinib: a new targeted therapy for hematologic cancers. Clin J Oncol Nurs. 2015. V. 19. P. E47-E51. https://doi.org/10.1188/15.CJON.E47-E51.

4. Ali I. Nano drugs: novel agents for cancer chemo-therapy. Curr Cancer Drug Targets. 2011. V. 11. P. 130.

5. Clinical applications of nanomedicine in cancer therapy. M. Norouzi, M. Amerian, M. Amerian, F. Atyabi. Drug Discov Today. 2019. pii: S1359-6446(19)30377-0. https://doi.org/10.1016/ j.drudis.2019.09.017.

6. Экспериментальная оценка противоопухолевых препаратов в СССР и США; под ред. З. П. Софьиной и др. Москва : Медицина, 1980. 296 с.

7. Current Protocols in Toxicology; ed. M. Maines. N. Y. : John Wiley \& Sons, Inc., 2005. 2758 p.

8. Великов В. А. Молекулярная биология. Практическое руководство: учеб. пособие для студ. биол. фак. и фак. нано- и биомед. технол., обучающихся по напр. «Биология (020400)», «Биология-пед (050100)", «Биотехнические системы и технологии (200100)», «Медицинская физика (011200)» и по спец. «Биоинженерия и биоинформатика (020501)». Саратов : Издательство «Саратовский источник», 2013. 84 с.

9. Орехович В. Н. Современные методы в биохимии. Москва : Медицина, 1977. С. 313-316.

10. Agarose Gel Electrophoresis for the Separation of DNA Fragments. P. Lee, J. Costumbrado, C. Hsu, Y. Kim. Journal of Visualized Experiments. 2012. V. 62. P. 3923.

11. Sedlak J., Lindsay R. H. Estimation of total, protein-bound, and non protein sulfhydryl groups in tissue with Ellman's reagent. J. Sedlak. Analytical Biochemistry. 1968. V. 25. P. 192-205.

12. DMBA-induced cytotoxicity in lymphoid and nonlymphoid organs of B6C3F1 mice: relation of cell death to target cell intracellular calcium and DNA damage. S. W. Burchiel, D. A. Davis, S. D. Ray et al. Toxicol. Appl. Pharmacol. 1992. V. 113. P. 126-132.

13. Induction of Cytochrome P450 2E1 Increases Hepatotoxicity Caused by Fas Agonistic Jo2 Antibody in Mice. X. Wang, Lu Y. Yongke, A. I. Cederbaum. Hepatology. 2005. V. 42. P. 400-411.

14. Erol A. Systemic DNA damage response and metabolic syndrome as a premalignant state. Curr. Mol. Med. 2010. № 10, V. 3. P. 321-334.

15. Комбінований вплив екзогенних оксидів азоту та малих доз іонізуючої радіації на розвиток генетичної нестабільності та утворення вільнорадикальних сполук при пухлинному рості. О. А. Главін, Б. І. Геращенко, Н. М. та ін. Сучасні проблеми токсикології. 2011. Т. 5. С. 108-109.

16. Лукашова О. П. Действие ионизирующей радиации и препарата «Этопозид» на процессы апоптоза и ультраструктуры клеток карциномы Герена. Український радіологічний журнал. 2013. T. 21. C. $56-63$. 
17. Індукуючі апоптоз засоби для лікування злоякісних пухлин, імунологічних і автоімунних захворювань. Э. Дж. Сауэрс, С. Ван, Дж. Салливан и др. Патент США. - C07D471/04, C07D463/00,A61P35/00, A61K31/437. URL: http://www.findpatent.ru/patent/266/ 2662812.html

18. Ceramide-induced cell death in malignant cells. A. Carpinteiro, C. Dumitru, M. Schenck, E. Gulbins. Cancer Letters. 2008. V. 264. P. 1-10.

19. Вплив поєднаної дії іонізуючого випромінювання та хіміопрепаратів на вміст проапоптозного ліпіду цераміду в карциномі Герена. Т. Сегеда, Н. Мітряєва, Т. Бакай, Л. Гребіник. Вісник Львівського університету. Серія біологічна. Вип. 60. 2012. С. 111-116.

20. Bulow J. F. RNA-DNA ratios as indicators of growth rates in fish: A review. In: Summerfelt RC, Hall GE, editors. The age and growth of fish. Ames, lowa : The lowa State University Press, 1987. P. 45-64.

21. Robinson S. M., Ware D. Ontogenetic development of growth rates in larval Pacific herring, Clupea harengus pallasi, measured with RNA/DNA ratios in the Strait of Georgia, British Columbia. Can. J. Fish. Aquat. Sci. 1988. V. 45. P. 1422-1429.

22. Новичков Е. В., Вотинцев А. А. Значение гистоспектрофотометрических параметров опухоли в прогнозе метастазирования серозной овариальной карциномы. Пермский медицинский журнал. 2006. № 23. С.113-127.

23. Морфология внутренних органов и опухоли лабораторных крыс с перевитым раком печени Pc-1 при пероральном введении флавоноидсодержащих экстрактов аврана лекарственного (Gratiola Officinalis L.) и кукурузы антоциановой (Zea Mays L.). Н. А. Наволокин, Н.В.Полуконова, Г. Н. Маслякова и др. Саратовский научно-медицинский журнал. 2013. Т. 9. С. 213-237.

24. Traganos F., Darzynkiewicz Z., Melamed M. R. The ratio of RNA to total nucleic acid content as a quantitative measure of unbalanced cell growth. Cytometry: The Journal of the International Society for Analytical Cytology. 1982. V. 2. P. 212-218.

25. Hutcheson R., Rocic P. The Metabolic Syndrome, Oxidative Stress, Environment, and Cardiovascular Disease: The Great Exploration. Experimental Diabetes Research. 2012. V. 2012. P. 1-13.

\section{Л. Б. Бондаренко, Т. А. Карацуба, О. О. Хавич, Г. М. Шаяхметова, Н. І. Шарикіна, В. М. Коваленко, Р. О. Стратійчук, А. А. Коновалов, М. М. Калачінська \\ Вплив Іфітинібу на складові хроматину та стан антиоксидантної системи в карциномі Герена та незмінених тканинах матки}

Неспецифічна дія протипухлинної хіміотерапії на прилеглі до пухлини тканини сама по собі здатна погіршити стан організму додатково до наслідків розвитку неопластичного процесу і навіть справити вирішальну роль у виживанні організму. Тому актуальним $є$ проведення паралельних досліджень впливу нових протипухлинних засобів на етапі доклінічних випробувань як на пухлини, так і на тканини того самого організму, які неуражені неопластичним процесом, для подальшої оптимізації хіміотерапії.

Мета дослідження - вивчити вплив Іфітинібу на ДНК, РНК, білки хроматину, процеси фрагментації ДНК, вміст небілкових і пов'язаних з білками SH-груп у карциномі Герена та незмінених тканинах матки.

Дослідження впливу Іфітинібу проводили на білих щурах-самицях лінії Вістар. Тварини були розподілені за методом рандомізації на 3 групи по 6 тварин у кожній: 1 - інтактні щури, 2 - негативний контроль (карцинома Герена), 3 - карцинома Герена + 29,93 мг/кг Іфітинібу.

Вивчення впливу Іфітинібу на ДНК, РНК, білки хроматину, процеси фрагментації ДНК, вміст небілкових і пов'язаних з білками SH-груп у карциномі Герена та незмінених тканинах матки показало, що даний препарат вірогідно змінював більшість досліджуваних показників як порівняно з інтактними тваринами, так і з карциномою Герена без лікування. Специфічність впливу Іфітинібу на клітини пухлин була найвираженішою у випадку ДНК-фрагментації та змін вмісту небілкових і пов'язаних з біл-

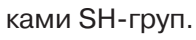

Ключові слова: Іфітиніб, карцинома Герена, ДНК, РНК, фрагментація, антиоксидантна система

\section{Л. Б. Бондаренко, Т. А. Карацуба, О. А. Хавич, А. М. Шаяхметова, \\ Н. И. Шарыкина, В. Н. Коваленко, Р. А. Стратийчук, А. А. Коновалов, \\ М. Н. Калачинская \\ Влияние Ифитиниба на составляющие хроматина и состояние антиоксидантной системы в карциноме Герена и неизмененных тканях матки}

Неспецифическое действие противоопухолевой химиотерапии на прилегающие к опухоли ткани само по себе способно ухудшить состояние организма дополнительно к последствиям развития неопластического процесса в нем и даже оказать решающую роль в выживании организма. Поэтому актуальным является проведение параллельных исследований влияния новых противоопухолевых средств на этапе доклинических испытаний как на опухоли, так и на ткани того же самого организма, непораженные неопластическими изменениями, для дальнейшей оптимизации химиотерапии. 
Цель исследования - изучить влияние Ифитиниба на ДНК, РНК, белки хроматина, процессы фрагментации ДНК, содержание небелковых и связанных с белками SH-групп в карциноме Герена и неизмененных тканях матки.

Исследование влияния Ифитиниба проводили на белых крысах-самках линии Вистар. Животные были рандомизированы на 3 группы по 6 животных в каждой: 1 - интактные крысы, 2 - отрицательный контроль (карцинома Герена), 3 - карцинома Герена + 29,93 мг/кг Ифитиниба.

Изучение влияния Ифитиниба на ДНК, РНК, белки хроматина, процессы фрагментации ДНК, содержание небелковых и связанных с белками SH-групп в карциноме Герена и неизмененных тканях матки показало, что данный препарат достоверно менял большинство исследуемых показателей как по сравнению с интактными животными, так и с карциномой Герена без лечения. При этом специфичность влияния Ифитиниба на клетки опухолей была наиболее выражена в случае ДНКфрагментации и изменений содержания небелковых и связанных с белками SH-групп.

Ключевые слова: Ифитиниб, карцинома Герена, ДНК, РНК, фрагментация, антиоксидантная система

\section{B. Bondarenko, T. A. Karatsuba, O. O. Khavich, G. M. Shayakhmetova, N. I. Sharykina, V. M. Kovalenko, R. O. Stratiychuk, A. A. Konovalov, \\ M. M. Kalachinska \\ The effect of Ifitinib on chromatin components and antioxidant system in Guerin's carcinoma and unchanged uterine tissues}

The non-specific effect of antitumor chemotherapy on the tissue adjacent to the tumor itself can worsen the organism's state additionally to the consequences of neoplastic process development and even may have a decisive role in the survival of the whole organism. Therefore, it is relevant to conduct parallel studies of the effect of new antitumor agents at the stage of preclinical trials on both tumors and tissues that are not affected by neoplastic changes in order to further optimization of chemotherapy.

Objective: to study the effect of Ifitinib on DNA, RNA, chromatin proteins, DNA fragmentation processes, the content of non-protein and protein-associated SH-groups in Guerin's carcinoma and unchanged uterine tissues.

A study was carried out on white Wistar female rats. Animals were randomized into 3 groups of 6 animals each: 1 - intact rats; 2 - negative control (Guerin's carcinoma) 3 - Guerin's carcinoma + 29.93 mg / kg Ifitinib. A study of Ifitinib effects on DNA, RNA, chromatin proteins, DNA fragmentation processes, the content of non-protein and protein-associated SH groups in Guerin's carcinoma and unchanged uterine tissues showed that this drug significantly changed the majority of the studied parameters both in comparison with intact animals and with Guerin's carcinoma without treatment. Moreover, the specificity of Ifitinib influence on tumor cells was most pronounced in the case of DNA fragmentation and changes in the content of non-protein and protein-associated SH-groups.

Key words: Ifitinib, Guerin's carcinoma, DNA, RNA, fragmentation, antioxidant system

Надійшла: 22 серпня 2019 р.

Прийнята до друку: 16 жовтня 2019 р.

Контактна особа: Бондаренко Л. Б., ДУ «Інститут фармакології та токсикології НАМНУ», буд. 14, вул. Антона Цедіка, м. Київ, 03057 . Тел.: + 380444564256. 